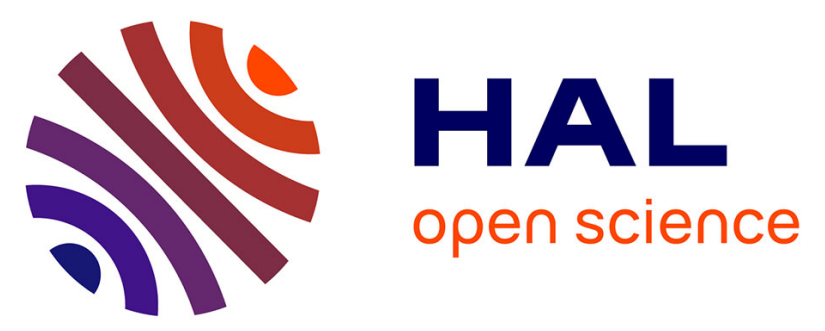

\title{
ARE ONE EARLY MUSCLE PH AND TEMPERATURE MEASUREMENTS SUFFICIENT TO DETECT PSE BREAST MEAT IN TURKEYS?
}

Hervé Rémignon, Caroline Molette, Xavier Fernandez, Sunee Eadmusik

\section{- To cite this version:}

Hervé Rémignon, Caroline Molette, Xavier Fernandez, Sunee Eadmusik. ARE ONE EARLY MUSCLE PH AND TEMPERATURE MEASUREMENTS SUFFICIENT TO DETECT PSE BREAST MEAT IN TURKEYS?. British Poultry Science, 2011, 52 (02), pp.177-188. 10.1080/00071668.2011.554798 . hal-00686676

\section{HAL Id: hal-00686676 https://hal.science/hal-00686676}

Submitted on 11 Apr 2012

HAL is a multi-disciplinary open access archive for the deposit and dissemination of scientific research documents, whether they are published or not. The documents may come from teaching and research institutions in France or abroad, or from public or private research centers.
L'archive ouverte pluridisciplinaire HAL, est destinée au dépôt et à la diffusion de documents scientifiques de niveau recherche, publiés ou non, émanant des établissements d'enseignement et de recherche français ou étrangers, des laboratoires publics ou privés. 


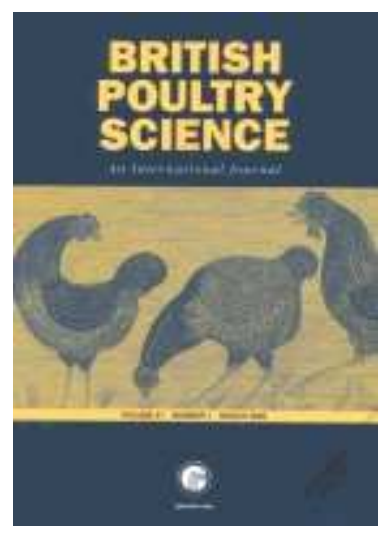

\section{ARE ONE EARLY MUSCLE PH AND TEMPERATURE MEASUREMENTS SUFFICIENT TO DETECT PSE BREAST MEAT IN TURKEYS?}

\begin{tabular}{|c|c|}
\hline Journal: & British Poultry Science \\
\hline Manuscript ID: & CBPS-2009-095.R1 \\
\hline Manuscript Type: & Original Manuscript \\
\hline $\begin{array}{r}\text { Date Submitted by the } \\
\text { Author: }\end{array}$ & 27-May-2010 \\
\hline Complete List of Authors: & $\begin{array}{l}\text { Remignon, Herve; INPT, ENSAT-Animal Sciences } \\
\text { MOLETTE, Caroline; INPT-ENSAT, Animal Sciences } \\
\text { FERNANDEZ, Xavier; INRA, UMR tandem } \\
\text { Eadmusik, Sunee; INPT-ENSAT, Animal Sciences }\end{array}$ \\
\hline Keywords: & Meat, Turkeys, Protein \\
\hline
\end{tabular}

\section{SCHOLARONE Manuscripts}


2 Are one early muscle pH and one early temperature measurement sufficient to detect

$3 \quad$ PSE breast meat in turkeys?

4

\section{S. EADMUSIK ${ }^{1,2}$, C. MOLETTE ${ }^{1,2}$, X. FERNANDEZ ${ }^{2}$ AND H. RÉMIGNON ${ }^{1,2}$}

6

$7 \quad{ }^{1}$ Université de Toulouse, INPT, ENVT, UMR 1289 Tandem, Tissus Animaux, Nutrition,

8 Digestion, Ecosystème et Métabolisme; ENSAT, F-31326 Castanet-Tolosan Cedex, France,

9 and ${ }^{2}$ INRA, Auzeville, F-31326 Castanet-Tolosan, France

10

11

12

13

14

15

16

17

18

19

\section{Running title: PSE breast meat in turkeys}

Correspondence to: Prof. Hervé Rémignon, Université de Toulouse, INPT, ENVT, UMR 1289 Tandem, Tissus Animaux, Nutrition, Digestion, Ecosystème et Métabolisme; ENSAT, F-31326 Castanet-Tolosan Cedex, France.

2 E-mail: remignon@ensat.fr

Accepted for publication 13th October 2010 
26 Abstract 1. Within a large flock of turkey toms (2000 BUT9 conventionally reared and 27 slaughtered), early muscle $\mathrm{pH}$ measurements were randomly done to distinguish two groups 28 of birds presenting low (fast glycolysing, GR) or normal (normal glycolysing, GN) values.

29 2. Subsequently, ultimate $\mathrm{pH}$ values and meat quality parameters were also recorded. Meat 30 quality parameters from GR or GN samples differ more or less indicating more or less severe 31 PSE conditions. Proteins extracted from the samples at 20 min post mortem were quite similar 32 while they greatly differ at $24 \mathrm{~h}$ post mortem. Moreover, among the GR birds, a subgroup of 33 animals (called $\mathrm{AB}$ ) presented SDS-PAGE profiles largely different from other GR or GN 34 birds.

35 3. All the subsequent analysis developed on meat quality parameters as well as for protein 36 extractabilities also differ between $\mathrm{AB}$ and other animals indicating that they must be 37 considered differently in term of PSE syndrome development.

38 4. Western blots against Myosin Heavy Chain and actin at $24 \mathrm{~h}$ post mortem indicate that 39 myofibrillar proteins alterations are different in AB and GR or GN samples.

40 5. At 20 min post mortem, glycogen content was lowest in AB samples while the glycolytic 41 potential was similar in all samples at the time of death. Measurements of PFK enzyme 42 specific activity did not indicate a different regulation of post mortem glycolysis in $\mathrm{AB}$ 43 samples.

44 6. Our results suggest that a unique $\mathrm{pH}$ measurement at $20 \mathrm{~min}$ post is insufficient to detect 45 animals more prone to developing a severe PSE syndrome in turkeys. In consequence, it is 46 suggested that a more precise evaluation of the kinetics of $\mathrm{pH}$ and temperature decrease has to 47 be conducted to understand the aetiology of meat quality parameters alterations in poultry. INTRODUCTION

49 Since the beginning of the 1990's, the PSE (Pale, Soft and Exudative) syndrome has been 50 given a lot of attention from poultry scientists, as well as meat processors, because of its 
51 adverse effects on poultry meat quality. In pigs, the genetic origin of the syndrome is well established (e.g., Barbut et al., 2008), but it remains obscure in poultry (Rémignon et al., 2007). Nevertheless, there is a large consensus in mammals, as well as in poultry, to consider that the combination of a low $\mathrm{pH}$ and a high temperature in post-mortem muscle is at the origin of protein alterations which lead to meat quality modifications (Alvarado and Sams, 2004). These alterations concern, to a greater or lesser extent, the colour of meat, its waterholding capacity, its texture and also its ability to succeed in meat-product enhancements like marination, curing-cooking processing or sausage elaboration (McKee and Sams, 1998; Wynveen et al., 1999; Alvarado and Sams, 2004).

Several facets of the production of live birds and/or management of carcases have been 61 investigated, mainly in turkeys and chickens (for review, Barbut et al., 2008), to describe the 62 factors which trigger the PSE syndrome. A lot of attention has also been given to the speed of post-mortem glycolysis, which is thought to be more important than the animal itself (Choi et al., 2007; Gratacos-Cubarsi and Lametsch, 2008; Molette et al., 2005; Hahn et al., 2002; Rathgeber et al., 1999a). Indeed, an acceleration of muscle glycolysis is required to produce qualities similar to those described when PSE or PSE-like syndrome develops (Warris and 74 Brown, 1987; Pietrzak et al., 1997; Rathgeber et al., 1999a; Wynveen et al., 1999; James et al., 2006). Nevertheless, all these studies have observed the consequence of the presence of 
76 both low $\mathrm{pH}$ and high temperature in poultry muscles at early times post-mortem, but no one 77 has yet proposed a clear origin of those conditions.

The measurement of early $\mathrm{pH}$ values cannot be generalised in processing plants because

it is destructive and not easy to perform. Soon after death, plasma membranes are still in their native form and most of the water present in the muscle is retained in the myofibrillar structure. Therefore, to have a good estimation of early $\mathrm{pH}$ values, it is absolutely necessary to grind muscle samples in a buffer and to be able immediately to stop the anaerobic glycolysis (iodoacetate is generally used as recommended by Jeacocke, 1977). On the contrary, after the setup of rigor mortis, a large part of the water have been expelled from the myofibrillar structure and released into the extracellular spaces after plasma membrane disruptions. Thus, a direct measurement of proton concentration is possible with an adapted (meat-type) $\mathrm{pH}$ electrode.

In consequence, although numerous studies are available on the variability of ultimate pH (pHu) values within a given flock (Fernandez et al., 2002; Hahn et al., 2002; Fraqueza et al., 2006), few have paid attention to this variability in $\mathrm{pH}$ measurements made soon after the birds have been slaughtered. Because muscle $\mathrm{pH}$ monitoring is not easily performed on a slaughter line, authors generally report only one early $\mathrm{pH}$ value (recorded at 15 or 20 min post-mortem) to define characteristics of fast or normal glycolysing muscles. Nevertheless, we must consider that post-mortem glycolysis is a dynamic phenomenon which cannot be described by a single measurement. The complexity of these measurements is increased if the monitoring of internal muscle temperature has also to be taken into account.

Besides this, conclusions coming from the comparison of fast and normal glycolysing muscles are not clear because some workers have reported alterations of sarcoplasmic (Warner et al., 1997; Joo et al., 1999; Rathgeber et al., 1999a) or myofibrillar proteins (McKee and Sams, 1998; Rathgeber et al., 1999a; Kuo and Chu, 2003). These protein 
101 alterations may concern phosphorylase (Pietrzak et al., 1997; Rathgeber et al., 1999a,b; 102 Alvarado and Sams, 2004) or creatine kinase (Rathgeber et al., 1999b) or, for example, 103 myokinase or triose phosphate isomerase and myosine (Rathgeber et al., 1999b) or 104 cytoskeletic proteins such as titin (Warner et al., 1997).

105 In the present study, we investigated whether all turkeys which exhibit a low early $\mathrm{pH}$ 106 value (20 min post-mortem) must be considered as a whole or if some of them could exhibit 107 different protein alterations which could make them more or less typical of the PSE 108 syndrome. To be sure that all the finally observed meat quality alterations were only due to 109 different glycolytic rates, all the birds were initially randomly selected from a commercial 110 flock with special attention being given to ultimate $\mathrm{pH}$ value $(\mathrm{pHu})$ and glycogen reserves to 111 ensure that the amplitude of the decline in $\mathrm{pH}$ did not interact with the rate of $\mathrm{pH}$ fall. MATERIALS AND METHODS

\section{Animals}

114 A flock of 2000 turkey toms (line BUT9, BUT Ltd., Chester, UK), was reared in a 115 commercial farm to 19 weeks of age (average live weight $=15 \mathrm{~kg}$ ). All the birds were fasted 116 for $10 \mathrm{~h}$ before slaughter and then conventionally processed in a slaughter-house (Gastronome 117 SA, Moncoutant, France).

118 Sampling

119 At the end of the slaughtering process, the $\mathrm{pH}$-values of 458 breast muscles (Pectoralis major, $120 \mathrm{Pm}$ ) were randomly measured $\left(\mathrm{pH}_{20 \mathrm{~min}}\right)$ according to Jeacocke (1977). Two grams of breast 121 muscle were homogenised in $18 \mathrm{ml}$ of $5 \mathrm{mM}$ iodoacetate using an Ultra Turrax (IKA122 WERKE, Staufen, Germany). The $\mathrm{pH}_{20 \text { min }}$ was then measured by using a portable $\mathrm{pH}$-meter 123 combined with a glass electrode. The internal breast muscle temperature was also measured at $12420 \mathrm{~min}$ post-mortem and $20 \mathrm{~g}$ of muscle were collected and immediately frozen in liquid 125 nitrogen. 
Two groups were then sorted according to their $\mathrm{pH}_{20 \min }$ values from all the measured

127 animals: the first one (Normal Glycolysis, GN, $n=20$ ) was made up with animals showing

$128 \mathrm{pH}_{20 \min }$ values similar to the mean value $(6.21 \pm 0.01)$ of the whole population, while the

129 second one (Rapid Glycolysis, GR, $\mathrm{n}=20$ ) was made up with birds presenting the lowest

$130 \mathrm{pH}_{20 \min }$ values $(5.80 \pm 0.07)$. Following storage overnight at $4^{\circ} \mathrm{C}, \mathrm{pHu}$ was then directly

131 measured by inserting a glass pH-probe into the Pm muscle in GN and GR samples. At $24 \mathrm{~h}$

132 post-mortem, other $\mathrm{Pm}$ samples were harvested as described above and kept at $-80^{\circ} \mathrm{C}$ until

133 analysed.

\section{Meat quality measurements}

135 Colour

136 Meat colour was measured at $24 \mathrm{~h}$ post-mortem on the belly part of the breast meat with a

137 Minolta CR-300 chromameter (Osaka, Japan) The instrument was set to measure CIE L*, a*,

$138 \quad \mathrm{~b}^{*}$ values using illuminant $\mathrm{D}$ and $65^{\circ}$ standard observer.

139 Water-holding capacity

140 Drip loss was evaluated on scallops (around $100 \mathrm{~g}$ ) of breast muscle collected $1 \mathrm{~d}$ post141 mortem. The scallops were then stored for $9 \mathrm{~d}$ at $4{ }^{\circ} \mathrm{C}$ in a polystyrene tray covered with a

142 scattering film (air permeable). After final weighing, drip loss was expressed as a percentage 143 of the initial weight at $1 \mathrm{~d}$ (Honikel, 1998). After $9 \mathrm{~d}$ of storage, the scallops were weighed

144 (pre-thaw weight) and frozen at $-20^{\circ} \mathrm{C}$ for 2 weeks. They were allowed to thaw overnight at

$1454{ }^{\circ} \mathrm{C}$ and were then reweighed (precook weight). Thaw loss was expressed as a percentage of 146 the pre-thawing weight. The thawed meat was further used to evaluate cook loss and sausage 147 yield. The scallops were vacuum-packaged and cooked in an $80^{\circ} \mathrm{C}$ water bath for 15 min. 148 After cooking, samples were then cooled down to room temperature, rapidly wiped and 149 weighed. Cooking loss was expressed as a percentage of the precooking weight.

$150 \quad$ Meat batter yield 
151 Sausages were produced following the method described by Shand et al. (1994). Thawed 152 meat $(52.5 \mathrm{~g})$ was trimmed, chopped and mixed with iced water $\left(21 \mathrm{~g}, 0^{\circ} \mathrm{C}\right)$ and salt $(1.5 \mathrm{~g})$ for 15325 s using a Moulinex ILLICO (Lyon, France) blender. The meat batter was then transferred 154 to a plastic bag and vacuum packaged (residual pressure $<10 \mathrm{mb}$ ) to remove air bubbles. 155 Twenty grams of meat batter were poured into a polypropylene tube and centrifuged at $700 \mathrm{~g}$ 156 at $4^{\circ} \mathrm{C}$ for $10 \mathrm{~min}$. The tubes were then placed in a hot water bath until the internal 157 temperature of meat paste reached $80^{\circ} \mathrm{C}$. After cooling down, the tubes were removed and the 158 sausages were weighed. The yield was expressed as a percentage of initial weight.

\section{Warner-Bratzler shear test}

160 The texture of cooked meat was evaluated according to Honikel (1998). A 1-cm-wide strip of 161 cooked meat was obtained by cutting parallel to the longitudinal axis of the scallop myofibres.

162 Shear force was measured using a MTS Synergie 200 apparatus (MTS, Eden Prairie, MN, 163 USA). The maximum force needed to shear the sample represented the meat tenderness and 164 was expressed in Newtons.

\section{Protein extractability}

166 Muscular proteins of Pm samples collected at $20 \mathrm{~min}$ and $24 \mathrm{~h}$ post-mortem were extracted 167 following the methods of Rathgeber et al. (1999a) and Boles et al. (1992). One gram of 168 sample was homogenised in $20 \mathrm{ml}$ of a low ionic strength (LIS) buffer, containing $0.05 \mathrm{M}$ 169 potassium phosphate buffer, $1 \mathrm{mM} \mathrm{NaN}_{3}$ and $2 \mathrm{mM} \mathrm{EDTA} / \mathrm{pH} 7.3$ at $2{ }^{\circ} \mathrm{C}$ for $10 \mathrm{sec}$. The 170 homogenised sample was then agitated for $30 \mathrm{~min}$ at $4^{\circ} \mathrm{C}$ and centrifuged at $17500 \mathrm{~g}$ at $2^{\circ} \mathrm{C}$ 171 for $15 \mathrm{~min}$. Ten millilitres of the supernatant (LIS fraction) were collected at $2 \mathrm{~cm}$ above the 172 bottom of the tube while the remaining supernatant was discarded. A supplemental $20 \mathrm{ml}$ LIS 173 buffer was added to resuspend the pellet which was then homogenised, agitated and 174 centrifuged as previously describe. The supernatant was discarded and the procedure was 175 repeated with high ionic strength (HIS) buffer, containing $0.55 \mathrm{M} \mathrm{KCl}, 0.05 \mathrm{M}$ potassium 
176 phosphate buffer, $1 \mathrm{mM} \mathrm{NaN}_{3}$ and $2 \mathrm{mM} \mathrm{EDTA/pH} 7.3$ at $2^{\circ} \mathrm{C}$. Following centrifugation, 10

$177 \mathrm{ml}$ of supernatant (HIS fraction) was collected as described above and the excess supernatant

178 removed. The pellet was re-suspended in $40 \mathrm{ml}$ of potassium phosphate buffer containing 75

$179 \mathrm{mM} \mathrm{KCl}, 10 \mathrm{mM} \mathrm{KH}_{2} \mathrm{PO}_{4}, 2 \mathrm{mM} \mathrm{MgCl}$ and $2 \mathrm{mM}$ EGTA/pH 7 and sonicated (Sonificateur,

180 Bioblock Scientific, Illkirch, France) for $1 \mathrm{~min}$ to solubilise the fraction (pellet fraction).

181 Protein content in LIS, HIS and pellet fractions were determined by the BCA protein assay kit

182 (PIERCE, Rockford, IL, USA). Results are expressed as a percentage of total proteins.

183 Sodium Dodecyl Sulphate-PolyAcrylamide Gel Electrophoresis (SDS-PAGE)

184 SDS-PAGE was performed in order to separate proteins in each buffer-extracted fraction from 185 samples collected at $20 \mathrm{~min}$ and $24 \mathrm{~h}$ post-mortem. Samples containing $2 \%(\mathrm{w} / \mathrm{v})$ SDS, $5 \% \beta$ 186 mercaptoethanol, $10 \%$ glycerol and $62 \mathrm{mM}$ Tris- $\mathrm{HCl}, \mathrm{pH} 6.8$ in a ratio 1:1 v/v (Laemmli, 187 1970) were heated at $95^{\circ} \mathrm{C}$ for $5 \mathrm{~min}$. SDS-PAGE was performed following the method 188 described by Laemmli (1970) using a Mini-Protean II electrophoresis unit or a Protean Xi 189 Unit (Bio-Rad Laboratories Inc., Hercules, CA, USA). Samples were loaded at $40 \mu \mathrm{g}$ protein 190 per lane for LIS, HIS and pellet fractions, 5 and $10 \mu \mathrm{g}$ for western blots of actin and Myosin 191 Heavy Chain (MHC), respectively. Resolving gel of $12 \%$ polyacrylamide was used for LIS

192 fraction and 8\% polyacrylamide was applied for HIS and pellet fractions and western blots of 193 actin and MHC. Gels were run at $17 \mathrm{~mA}$ or $35 \mathrm{~mA} / \mathrm{gel}$ (for Mini-Protean II and Protean Xi 194 Units, respectively), constant current, until the dye front reached the bottom of the gel. Gels 195 were stained overnight in Coomassie brilliant blue R-250 containing 5\% (v/v) glacial acetic 196 acid, and 45\% (v/v) ethanol. Gels were then destained twice in the same solution excluding 197 Coomassie blue.

\section{Western blots of Actin and Myosin Heavy Chain}

199 HIS fraction was used to perform western blots of actin and MHC. Following SDS-PAGE, gel 200 was steeped into transfer buffer containing $25 \mathrm{mM}$ Tris, $192 \mathrm{mM}$ glycine and 20\% v/v 
201 methanol for $20 \mathrm{~min}$ (Towbin et al., 1979). Proteins were transferred to nitrocellulose 202 membrane (Hybond ECL, Amersham, Munich, Germany) at $30 \mathrm{~V}$ overnight using a transfer 203 cell (EBU 4000, CBS scientific, CA, USA). Membrane was blocked with milk buffer 204 containing 3\% w/v milk powder in phosphate buffer saline (PBS, pH 7.5) at room temperature 205 (RT) for $1 \mathrm{~h}$. Following blocking, membrane was probed for specific proteins using primary 206 antibody (mouse anti-actin, MAB 1501, Chemicon, CA, USA; mouse anti-myosin, F59, 207 DSHB, IA, USA) at RT for $2 \mathrm{~h}$. The primary antibody to milk buffer ratio was 1:1000 and 208 1:25 for actin and MHC respectively. The membrane was then washed 3 times with PBS and 209 incubated in secondary antibody (goat anti-mouse IgG, AP 127, Chemicon, CA, USA) at RT 210 for $1.5 \mathrm{~h}$. The secondary antibody to milk buffer ratio was 1:50,000 for actin and 1:25,000 for 211 MHC. Following this incubation, the membrane was washed 3 times and the 212 chemiluminescent substrate (Super Signal ${ }^{\circledR}$ West Pico, PIERCE) used to detect the reactivity 213 of the primary antibody with its antigen.

214 The Western blot was photographed by making a contact between the membrane and a 215 photo film (Amersham HyperfilmMP, GE Healthcare, Munich, Germany). The film was then 216 developed in 10\% revelation solution (AL4, Kodak, NY, USA), distilled water and 10\% 217 fixation solution (LX24, Kodak, NY, USA) for 1 min each, respectively. The amount of 2 and $2185 \mu \mathrm{g}$ proteins of chicken breast muscle were used as reference amounts for actin and MHC 219 respectively. Band intensity of samples was then measured by using Image Analysis 220 (ImageMaster 2D Platinum 6.0, GE Healthcare, NJ, USA). It was expressed as a percentage 221 of reference protein (actin and MHC of chicken breast muscle).

\section{Parameters of energetic metabolism}

223 Assays of phosphofructokinase (PFK) and Cytochrome c Oxidase (COX) activities

224 About $200 \mathrm{mg}$ of $\mathrm{Pm}$ muscle was collected at $20 \mathrm{~min}$ post-mortem and homogenised with 4 $225 \mathrm{ml}$ of buffer containing $0.25 \mathrm{M}$ sucrose, $2 \mathrm{mM}$ EDTA and $10 \mathrm{mM}$ Tris-HCL (pH 8.0) for $30 \mathrm{~s}$ 
226 at $4{ }^{\circ} \mathrm{C}$. The enzyme extract was obtained from centrifugation at $10000 \mathrm{~g}$ for $5 \mathrm{~min}$ at $4^{\circ} \mathrm{C}$. The 227 supernatant was collected and stored at $0^{\circ} \mathrm{C}$. Activity of PFK was spectophotometrically 228 measured in the presence of pyruvate kinase (PK) and lactate dehydrogenase (LDH) by using 229 a UVIKON 943 spectrometer (Kontron Instruments, Watford, UK) to follow a disappearance 230 of co-substrate $(\mathrm{NADH})$ at $340 \mathrm{~nm}$ and $25^{\circ} \mathrm{C}$ for $2 \mathrm{~min}$ (Beutler, 1971). The reaction was 231 assayed by mixing $1 \mu \mathrm{l}$ of enzyme extract with $1 \mathrm{ml}$ of solution containing $0.07 \mathrm{M}$ Tris- $\mathrm{HCl}$ 232 (pH 8), $1.4 \mathrm{mM} \mathrm{MgCl} 2,4.5 \mathrm{mM} \mathrm{KCL}, 0.71 \mathrm{mM}$ phosphophenol pyruvate, $0.65 \mathrm{mM}$ fructose233 1,6- diphosphate, $0.4 \mathrm{mM}$ NADH, $1 \mathrm{mM}$ ATP, $1.8 \mathrm{mM}$ fructose-6-phosphate, $0.08 \mathrm{U}$ PK and $2340.96 \mathrm{U}$ LDH. The PFK activity was expressed as $\mu$ mol of NADH disappeared per min and per $235 \mathrm{~g}$ of muscle $(\mu \mathrm{mol} / \mathrm{min} / \mathrm{g})$.

236 The preparation of enzyme extract for COX activity was performed as described above 237 except that, after centrifugation, the supernatant was frozen and defrosted 4 times in liquid 238 nitrogen to break cell wall and to release the enzyme contained in the mitochondrial matrix. 239 The enzyme extract was kept at $-20^{\circ} \mathrm{C}$ until used. Twenty $\mu 1$ of enzyme extract were mixed 240 with $1 \mathrm{ml}$ of solution ( $\mathrm{pH} 7.4$ ) containing $90 \mu \mathrm{M}$ Cytochrome c (reduced form) and $50 \mathrm{mM}$ 241 potassium phosphate (Smith and Conrad, 1956). The activity was assayed at $550 \mathrm{~nm}$ and $24225^{\circ} \mathrm{C}$. The COX activity was expressed as micromoles of Cytochrome c (reduced form) 243 disappeared per min and per $\mathrm{g}$ of muscle .

244 Glycogen, glucose, G-6-P, lactate and glycolytic potential determination

245 Amounts of glycogen, glucose, glucose-6-phosphate (G-6-P) and lactate of Pm muscle 246 collected at $20 \mathrm{~min}$ and $24 \mathrm{~h}$ post-mortem were measured by enzymatic procedures according 247 to Dalrymple and Hamm (1973) and Bergmeyer et al. (1974). About $200 \mathrm{mg}$ of Pm muscle 248 was homogenised in $10 \mathrm{ml}$ of $0.5 \mathrm{M}$ perchloric acid. Aliquots $(0.5 \mathrm{ml})$ of homogenate were 249 taken for the enzymatic determination of glycogen and G-6-P after glycogen hydrolysis with 250 amyloglucosidase. The rest of the homogenate was centrifuged and the supernatant was used 
251 for analysis of glucose, G-6-P and lactate. Glycogen content was calculated as the difference 252 between the results of the 2 sets. Lactate was determined in the supernatant resulting from the 253 centrifugation of the homogenate $(20 \mathrm{~min}$ at $2500 \mathrm{~g})$. Results were expressed in $\mu \mathrm{mol} / \mathrm{g}$ of 254 fresh tissue. Glycolytic potential was then calculated according to Monin and Sellier (1985) as 255 follows: $\mathrm{GP}=2[($ glycogen $)+($ glucose $)+($ glucose- $6-$ phosphate $)]+($ lactate $) . \quad$ It was 256 expressed as $\mu \mathrm{mol}$ of lactate equivalent per $\mathrm{g}$ of fresh meat.

\section{Statistics}

258 Experimental data were analysed using the GLM-general factorial ANOVA procedure using 259 the SAS software system for Windows statistical package, version 9.1 (SAS Institute Inc., 260 Cary, NC, USA). The GLM model was $Y_{i j}=\mu+G_{i}+e_{i j}$, where $Y_{i j}=$ dependent observation; $\mu$ $261=$ overall mean; $G_{i}=$ effect of Group $(\mathrm{i}=\mathrm{AB}, \mathrm{GR}-\mathrm{AB}$ and $\mathrm{GN}$ in a model or GR and GN in 262 another one) and $e_{i}=$ the residual error. Statistical significant effects were further analysed and 263 means compared using Student-Newman-Keuls multiple range test. Statistical significance 264 was determined at $P<0.05$.

\section{RESULTS}

266 SDS-Page profiles are reported in Figure 1. For the different proteins extracted at $20 \mathrm{~min}$ 267 post-mortem, gel patterns were very similar indicating that samples from the different groups 268 of birds probably contained the same proteins. In contrast, at $24 \mathrm{~h}$ post-mortem, if 269 sarcoplasmic proteins (LIS buffer extracted) presented the same profile, noticeable differences 270 were present for HIS buffer and pellet protein extracts. Those differences concerned mainly 271 two bands, located at 200 and $45 \mathrm{kDa}$ respectively, which were identified by mass 272 spectrometry analysis (data not shown) as myosin heavy chain (MHC) and actin respectively. 273 Whereas all the GN samples presented similar SDS-Page profiles, GR samples could easily be 274 divided in two groups. The GR-AB (Fast Glycolysing animals not ABnormals) samples were 275 very similar to the GN ones while the $\mathrm{AB}$ (ABnormals Fast Glycolysing) ones exhibited 
276 lower intensities for the bands corresponding to $\mathrm{MHC}$ and actin proteins. Four AB samples 277 were easily identified creating a new subgroup representing $20 \%$ of the whole GR samples. 278 From these observations, it clearly appears that not all GR samples can be considered as 279 equivalent, at least for their proteome extracted with high or very high ionic strength buffers. Results presented in Figure 2 failed to show differences in the quantity of MHC and 281 actin extracted at $20 \mathrm{~min}$ post-mortem. However, at $24 \mathrm{~h}$ post-mortem, WB performed with 282 antibody against MHC and actin clearly distinguished AB samples from others ones. A larger 283 quantity of MHC was detected in the proteins extracted from GN samples. AB and GR-AB 284 samples could also be significantly distinguished. Nevertheless, results from the quantity of 285 actin extracted at that later time cannot be used to distinguish GN from GR samples or GR$286 \mathrm{AB}$ from $\mathrm{GN}$ ones, but $\mathrm{AB}$ samples exhibited significantly lower amount of actin extracted 287 than in all other samples. Figures 1 \& 2 and Table 1 near here 288 Twenty min post-mortem, there were few differences between the groups of birds in 289 the quantity of muscular proteins extracted by the different buffers, thus making the 290 consequences of an acceleration of the glycolysis post-mortem difficult to interpret (Table 1). 291 Nevertheless, it was noticed that higher quantities of proteins were present in HIS and pellet 292 extracts coming from GN samples. This indicated that the lowest soluble muscular proteins 293 were affected by an acceleration in the rate of glycolysis which made them less extractible.

294 This tended to be more evident if GR samples are distinguished as AB and GR-AB samples 295 because AB samples presented lower (HIS extracts) or similar values to those found in GR296 AB samples.

297 After the onset of rigor mortis (24 h post-mortem), LIS and HIS protein extracts 298 exhibited higher amounts in GN than in GR samples. This difference between fast and normal 299 glycolysing samples was also more evident when AB samples were distinguished from GR- 
$300 \mathrm{AB}$. In that case, all the $\mathrm{AB}$ samples were significantly different from the GN ones. This 301 indicated that $\mathrm{AB}$ samples were more distinct to $\mathrm{GN}$ than GR-AB ones.

302 Meat quality parameters reported in Table 2 show that initial pH values were similar 303 in $\mathrm{AB}$ and $\mathrm{GR}-\mathrm{AB}$ samples but lower in GR than in GN ones. In contrast, pHu values were 304 similar in all samples and within a normal range. Considering muscle temperature at 20 min 305 post-mortem, results indicated that values for GN, GR and GR-AB samples were similar 306 (around $42{ }^{\circ} \mathrm{C}$ ), while values from $\mathrm{AB}$ samples were slightly but significantly higher (around $30743^{\circ} \mathrm{C}$ ). Considering different water loss values, GR samples presented similar (thawing or 308 cook loss) or higher (drip losses) values than GN samples. Contrastingly, AB samples had 309 higher drip and cook loss than GR-AB or GN samples, while thawing ones were similar in all 310 groups. The processing yields obtained from meat batter preparation were not significantly 311 different for GN and GR samples, but it was significantly lower for $\mathrm{AB}$ than for GR-AB or 312 GN samples (82.11, 88.95 and 90.40 respectively). After cooking, GN meat samples 313 presented lower shear force values $\left(F_{\max }\right)$ than $G R$ ones, but $A B$ and GR-AB samples were 314 not found to be significantly different. Nevertheless, AB and GR-AB samples were still 315 significantly tougher than $\mathrm{GN}$ ones. Higher $\mathrm{L}^{*}$ values $(53.03 \pm 2.87)$ recorded for raw meat 316 samples also permitted to easily distinguish AB samples from other ones. However, L* values 317 were similar in GN and GR samples (49.06 \pm 2.92 and $50.14 \pm 2.51$ respectively). When $\mathrm{a}^{*}$ 318 values were significantly higher in GR samples than in GN ones, but not in GR-AB ones, they 319 were also significantly increased in samples coming from the AB group.

Table 2 near here

320 Glycolytic potential (GP) values were similar in all samples (Table 3) suggesting that

321 muscular reserves in carbohydrates at the time of death were not different between all the 322 animals. Nevertheless, soon after death, we can observe that glycogen content is higher in GN 323 than in all other samples. On the contrary, glucose content was lower in GN samples than in 324 GR ones and was similar in AB and GR-AB samples. Lactate was higher in GR than in GN 
325 samples but failed to distinguish AB to GR-AB samples. No significant differences among all 326 the animals were recorded for G6P. At the end of the rigor mortis onset ( $24 \mathrm{~h}$ post-mortem), 327 similar quantities of all the considered metabolites were measured in all samples. If small significant differences in COX enzyme specific activity (Figure 3) were 329 recorded in the different samples, a much higher value was reported for the PFK enzyme 330 specific activity: in GN samples, this value was approximately 6 fold higher than in GR, GR$331 \mathrm{AB}$ or $\mathrm{AB}$ samples. Table 3 and Figure 3 near here 332

\section{DISCUSSION}

333 Soon after death (20 min post-mortem), SDS-Page profiles were similar between all the 334 groups of birds. This demonstrates that the analysed samples were very close in term of 335 proteome composition, as already shown by Pietrzak et al. (1997) and Rathgeber et al. $336(1999 b)$, who reported that normal or fast glycosing muscles were not differently organised in 337 terms of constitutive or functional proteins. On the contrary, at the end of the rigor mortis 338 onset, SDS-Page profiles were similar for all extracted fractions in GN animals while they 339 allowed us to make a clear difference between the GR ones. This indicates that, despite the 340 fact that all the GR birds were initially identified as being homogenous for the characteristic 341 of the rate of glycolysis (same low initial $\mathrm{pH}_{20 \mathrm{~min}}$ values), a clear distinction could be found 342 among them, considering the consequences of this parameter on the solubility of muscular 343 proteins. This distinguishes $\mathrm{AB}$ from GR-AB birds. The relevance of the AB group was 344 initially based on differences of SDS-Page profiles for HIS and pellet extracts, mainly 345 because of different intensities for two bands located at 45 and $200 \mathrm{kDa}$. The identification of 346 the modified bands was made by mass spectrometry analysis and revealed the presence of 347 actin and myosin heavy chain (MHC) at 45 and $200 \mathrm{kDa}$ respectively. Alterations of 348 myofibrillar proteins due to the acceleration of post-mortem glycolysis had previously been 349 reported by Rathgeber et al. (1999b). Modifications of muscular proteins extractabilities were 
350 partly visible at 20 min post-mortem because $\mathrm{AB}$ samples always differed from GN, but not 351 completely from GR-AB ones (same value for pellet extract). At $24 \mathrm{~h}$ post-mortem, AB 352 samples differed widely not only from GN ones but also from GR-AB, mainly for HIS extracts which contained most of the extractable myofibrillar proteins. By using values of 354 extractabilities, AB samples could always be distinguishable from GN ones whatever the time 355 post-mortem or the considered fraction. In contrast and for all the considered fractions, GR356 AB samples were not always found to be different from the GN ones. Quantitative analysis of 357 the presence of actin and myosin within the different HIS fractions by WB confirmed that the 358 level of considered proteins was similar for all the samples at $20 \mathrm{~min}$ post-mortem. At $24 \mathrm{~h}$ 359 post-mortem, there were always significantly smaller amounts of actin and MHC present in $360 \mathrm{AB}$ samples than in other ones, indicating a different degree of those proteins alteration 361 between the different samples. Whereas these alterations of actin and MHC in fast 362 glycolysing muscles have previously been reported by Rathgeber et al. (1999b), Alvarado and 363 Sams (2004) reported no effect of post-mortem glycolysis acceleration on the extraction of 364 myofibrillar proteins, as observed here, if $\mathrm{AB}$ samples are excluded from the analysis by 365 comparing GR-AB with GN ones. This indicates that, depending on the presence or otherwise 366 of $\mathrm{AB}$ samples among GR ones, the occurrence of myofibrillar protein alterations is in 367 response to accelerated glycolysis post-mortem. The presence of an associated increase in 368 muscle temperature only in AB samples, together with a lack of any difference in pHu values, 369 suggests that AB samples must be considered as true PSE ones while GR-AB are probably 370 less affected. The percentage of AB samples among all the GR ones could then explain why 371 some authors found large effects on meat quality parameters due to accelerated post-mortem 372 glycolysis, while others concluded that the combination low early post-mortem $\mathrm{pH}$ and high 373 temperature values had a much smaller effect. It is generally accepted that the combination of 374 low $\mathrm{pH}$ and high temperature values, within muscle, leads to protein alterations (Joo et al., 
375 1999; Wilson; van Laack, 1999) and consequently modifies protein extractabilities as well as 376 meat quality (Alvarado and Sams, 2004; Gratacos-Cubarsi and Lametsch, 2008). To our 377 knowledge, but with the exception of a report by Offer (1991) who estimated the part of 378 myosin degraded in several $\mathrm{pH}$ and temperature conditions, neither the conditions nor the 379 duration of $\mathrm{pH}$ and temperature limit values have precisely been described. As a consequence, 380 we must ask what are the incorrect conditions for meat quality. For example, is a condition 381 described by a $\mathrm{pH}$ value lower than 6.0 and a temperature lower than $40^{\circ} \mathrm{C}$ during $10 \mathrm{~min}$ 382 worst than one described by a $\mathrm{pH}$ value of 6.2 and a temperature higher than $40^{\circ} \mathrm{C}$ during a 383 shorter or a longer time? As muscle to meat transformation is a dynamic phenomenon 384 depending on time, temperature and $\mathrm{pH}$ values, we could take into account these three 385 parameters to better predict consequences on the future of proteins and on associated meat 386 qualities.

All data collected to determine the energetic status of sampled muscles confirmed that $388 \mathrm{AB}$ as well as GR-AB had rapidly started post-mortem glycolysis. Indeed, GP level was the 389 same in all samples, which is in good accordance with observed similar pHu values because 390 GP directly reflects the level of stock energy at the time of death (Monin and Sellier, 1985, Le 391 Bihan-Duval et al., 2008). At the end of the onset of rigor mortis, all the recorded values for 392 energetic compounds were at the same level, indicating that the extent of post-mortem 393 glycolysis was at the same level in all samples, (Warris et al., 1988; El Rammouz et al., 394 2004). This was in good agreement with final $\mathrm{pHu}$ values. However, whereas glycogen and 395 glucose levels were higher in GR (including AB and GR-AB samples) than in GN at 20 min 396 post-mortem, the lactate content was the reverse. This demonstrated that glycolysis began 397 more quickly in GR than in GN muscles, as could be deduced from $\mathrm{pH}_{20 \text { min }}$ values (Shen et 398 al., 2006). In our study, lactate levels, which are mainly responsible for $\mathrm{pH}$ fall in post399 mortem muscles, were similar in $\mathrm{AB}$ and $\mathrm{GR}-\mathrm{AB}$ samples as were $\mathrm{pH}_{20 \text { min }}$ values. PFK 
400 enzyme is considered to be a key enzyme in anaerobic glycolysis because it can act as a 401 regulator of its efficiency. When the level of production of energy (i.e. ATP) is high within 402 the cell, the specific activity of PFK enzyme is reduced to economise the stock of glycogen 403 (Wegener and Krause, 2002). This is probably the case here at 20 min post-mortem because, 404 in GR samples, the mean $\mathrm{pH}$ value reported was low, indicating a high level of anaerobic 405 glycolysis. In contrast, the level of anaerobic glycolysis in GN samples stayed low (as 406 demonstrated by low levels of lactate and high $\mathrm{pH}_{20 \text { min }}$ values) while the PFK specific activity 407 remained high. In all samples, low values for specific activities of COX enzyme indicated that 408 all the samples were glycolytic muscles as previously observed in turkey PM (Opalka et al., 409 2004). No differences in the specific activity of the PFK enzyme were recorded between AB 410 and GR-AB samples, demonstrating that a difference in glycolysis regulation should exist 411 between all the GR and GN samples independently from PFK specific activity modulations. It 412 is likely that, at the beginning of the slaughtering process, some birds would have enhanced 413 their muscular glycolysis rate, as did GR, but only few (AB ones) were able to maintain it for 414 a longer time than the majority of the fast glycolysing ones (here the GR-AB samples). This 415 would probably lead to the worst combination of $\mathrm{pH}$ and temperature values in the muscle 416 and could explain the poorest final quality of meat (here for $\mathrm{AB}$ samples). However, the 417 origins of this deep disorder in post-mortem glycolysis in the muscle is still unknown.

418 When we consider meat quality parameters such as drip loss, cooking 1, colour values 419 (mainly $\mathrm{L}^{*}$ and $\mathrm{a}^{*}$ ) and processing yield, our conclusions on the effect of the acceleration of 420 glycolysis post-mortem are completely different if we compare AB, GR-AB or GR samples 421 with GN. With AB samples, most of the recorded parameters differ from GN, while the final 422 conclusions are much less evident with GR or GR-AB. For example, higher L* values of meat 423 in fast-glycolysing samples have been widely discussed, but some workers found this 424 parameter could be used to sort PSE samples (Barbut, 1997) while others failed to distinguish 
425 between them (Molette et al., 2002; Fraqueza et al., 2006). In this study, we demonstrated 426 that, depending on the origin of samples, $\mathrm{AB}$ or GR-AB group, one can find equal or higher $427 \mathrm{~L}^{*}$ values for meat samples with a low initial $\mathrm{pH}$ value than in normal ones. If we take as a 428 reference the cut-off value of $\mathrm{L}^{*}>52$, as proposed by Barbut (1997), we would sort all the 429 AB samples as being PSE ones, while all the GR-AB would be considered as the GN ones, 430 despite that they present very different early $\mathrm{pH}$ values. As a consequence, it seems clear that 431 only measuring one early $\mathrm{pH}$ value is not sufficient to accurately detect samples liable to 432 develop the meat quality alterations generally associated with PSE syndrome in poultry.

\section{Conclusion}

434 This paper demonstrates that a simple measurement of one early muscle $\mathrm{pH}$ value is probably 435 insufficient to satisfactorily distinguish turkeys prone to develop PSE syndrome and all the 436 associated consequences for the quality of meat. Indeed, if the presence of a high muscle 437 temperature and a low $\mathrm{pH}$ value in muscle are required to develop PSE syndrome, the 438 duration of the conditions encountered post-mortem are also fundamental. Further 439 experiments describing the precise kinetics of $\mathrm{pH}$ and temperature evolution post mortem are 440 necessary to adequatelyl understand the etiology of the syndrome. The different possible 441 combinations of ( $\mathrm{pH}$, temperature and duration) could have large consequences on muscle 442 proteins and variably affect meat quality. Other investigations are also required to understand 443 why, which and how some turkeys are able to develop such conditions of muscle to meat 444 transformation leading to the poorest final quality of poultry products.

\section{REFERENCES}

447 ALVARADO, C.Z. \& SAMS, A.R. (2002) The role of carcass chilling rate in the 448 development of pale, exudative turkey pectoralis. Poultry Science, 81: 1365-1370.

449 ALVARADO, C.Z. \& SAMS, A.R. (2004) Turkey carcass chilling and protein denaturation 450 in the development of Pale, Soft and Exudative meat. Poultry Science, 83: 1039-1046. 
451 BARBUT, S. (1997) Problem of pale soft exudative meat in broiler chickens. British Poultry 452 Science, 38: 355-358.

453 BARBUT, S., SOSNICKI, A.A., LONERGAN, S.M., KNAPP, T., CIOBANU, D.C., 454 GATCLIFFE., L.J., HUFF-LONERGAN, E. \& WILSON, E.W. (2008) Progress in reducing 455 the pale, soft and Exudative (PSE) problem in pork and poultry meat. Meat Science, 79: 4645663.

457 BERGMEYER, H.U., BERNT, E., SCHMIDT, F. \& STORK, H. (1974) D-Glucose. 458 Determination with hexokinase and glucose-6-phosphate dehydrogenase, in: BERGMEYER, 459 H.U. (Ed.) Methods of enzymatic analysis, Vol. 3, pp. 1196-1201 (New York, Academic 460 Press).

461 BEUTLER, E. (1971) Phosphofructokinase, in: BEUTLER, E. (Ed) Red cell metabolism. A 462 manual of biochemical methods, pp. 42- 44 (New York, Grune and Straton Inc).

463 BOLES, J.A., PARRISH JR., F.C., HUIATT, T.W. \& ROBSON, R.M. (1992) Effect of 464 porcine stress syndrome on the solubility and degradation of myofibrillar/cytoskeletal 465 proteins. Journal of Animal Science, 70: 454-464.

466 CHOI, Y.M., RYU, Y.C. \& KIM, B.C. (2007) Influence of myosin heavy- and light chain 467 isoforms on early post-mortem glycolytic rate and pork quality. Meat Science, 76: 281-288.

468 DALRYMPLE, R.H. \& HAMM, R. (1973) A method for the extraction of glycogen and 469 metabolits from a single muscle sample. Journal of Food Technology, 8: 439-444.

470 El RAMMOUZ, R., BABILÉ R. \& FERANDEZ, X. (2004) Effect of ultimate pH on the 471 physicochemical and biochemical characteristics on turkey breast muscle showing normal rate 472 of postmortem pH fall. Poultry Science, 83: 1750-1757.

473 FERnANDEZ, X., SANTÉ, V., BAÉZA, E., LEBIHAN-DUVAL, E., BERRI, C., 474 RÉMIGNON, H., BABILÉ, R., LE POTTIER, G. \& ASTRUC, T. (2002) Effects of the rate 475 of muscle $\mathrm{pH}$ post mortem $\mathrm{pH}$ fall on the technological quality of turkey meat. British Poultry 476 Science, 43: 245-252.

477 FRAQUEZA, M.J., CARdoso, A.S., FERREIRA, M.C. \& BARRETO, A.S. (2006) 478 Incidence of pectoralis major turkey muscles with light and dark colour in a Portuguese 479 slaughterhouse. Poultry Science, 85: 1992-2000.

480 GRATACOS-CUBARSI, M. \& LAMETSCH, R. (2008) Determination of changes in protein 481 conformation caused by $\mathrm{pH}$ and temperature. Meat Science, 80: 545-549.

482 HAHN, G., MALENICA, M. \& BRANSCHEID, W. (2002) The relationship between pH 483 decline post-mortem and biochemical and physico-chemical properties of turkey breast meat. 484 Archiv für Geflükelkunde, 65: 66-65. 
485 HONIKEL, K.O. (1998) Reference methods for the assessment of physical characteristics of 486 meat. Meat Science, 49: 447-457.

487 JAMES, C., VIANCENT, C., DE ANDRATE LIMA, T.I. \& JAMES, S.J. (2006) The primary 488 chilling of poultry carcass - a review. International Journal of Refrigeration, 29: 847-862.

489 JEACOCKE, R.E. (1977) The temperature dependence of anaerobic glycolysis in beef muscle 490 held in a linear temperature gradient. Journal of the Science of Food and Agriculture, 28: $491 \quad 551-556$.

492 JOO, S.T., KAUFFMAN, R.G., KIM, B.C. \& PARK, G.B. (1999) The relationship of 493 sarcoplasmic and myofibrillar protein solubility to colour and water-holding capacity in 494 porcine longissimus muscle. Meat Science, 5: 291-297.

495 KUO, C.C. \& CHU, C.Y. (2003) Quality characteristics of Chinese sausages made fromPSE 496 pork. Meat Science, 64: 441-449.

497 LAEMMLI, U.K. (1970) Cleavage of structural proteins during the assembly of the head of 498 bacteriophage T4. Nature, 227: 680-685.

499 LE BIHAN-DUVAL, E., DEBUT, M., BERRI, C.M., SELLIER, N., SANTE500 L'HOUTELliER, V., JEGO, Y. \& BEAUMONT, C. (2008) Chicken meat quality: genetic 501 variability and relationship with growth and muscle characteristics. BMC Genetics, 18: 9-53.

502 MCKEE, S.R. \& SAMS, A.R. (1998) Rigor mortis development at elevated temperature 503 induces pale exudative turkey meat characteristics. Poultry Science, 77: 169-174.

504 MOLETTE, C., RÉMIGNON, H. \& BABILE, R. (2003) Effect of rate of pH fall on turkey 505 breast meat quality. British Poultry Science, 44: 787-788.

506 MOLETTE, C., RÉMIGNON, H. \& BABILÉ, R. (2005) Modification of glycolyzing 507 enzymes lowers meat quality of turkey. Poultry Science, 84: 119-27.

508 MONIN, G. \& SELLIER, P. (1985) Pork of low technological quality with a normal rate of 509 muscle $\mathrm{pH}$ fall in the immediate post mortem period: The case of the Hampshire breed. Meat 510 Science, 13: 49-63.

511 OFFER, G. (1991) Modelling of the formation of Pale, Soft and Exudative meat: Effect of 512 chilling regime and rate and extend of glycolysis. Meat Science, 30: 157-184.

513 OPALKA, J.R., WICKE, M., GELLERICH, F.N., SCHMIDT, R., ROSNER, F., ZIERZ, S. \& 514 VON LENGERKEN, G. (2004) Mitochondrial function in turkey skeletal muscle--impact on 515 meat quality. British Poultry Science, 45: 367-379.

516 PETRACCI, M., FLETCHER, D.L. \& NORTHCUTT, J.K. (2001) The effect of holding 517 temperature on live shrink, processing yield, and breast meat quality of broiler chickens. 518 Poultry Science, 80: 670-675. 
519 PIETRZAK, M., GREASER, M.L. \& SOSNICKI, A.A. (1997) Effect of rapid rigor mortis 520 processes on protein functionality in pectoralis major muscle of domestic turkeys. Journal of 521 Animal Science, 75: 2106-2116.

522 RATHGEBER, B.M., PATO, M.D., BOLES, J.A. \& SHAND, P.J. (1999a) Rapid post 523 mortem glycolysis and delay chilling of turkey carcasses cause alterations to protein 524 extractability and degradation of breast muscle proteins. Journal of Agricultural and Food 525 Chemistry, 47: 2529-2536.

526 RATHGEBER, B.M., BOLES, J.A. \& SHAND, P.J. (1999b) Rapid post mortem pH decline 527 and delayed chilling reduce quality of turkey breast meat. Poultry Science, 78: 477-484.

528 RÉMIGNON, H., MOLETTE, C., EADMUSIK, S. \& FERNANDEZ X. (2007) Coping with 529 the PSE syndrome in poultry meat. Proceedings of the XVIII European Symposium on the 530 Quality of Poultry Meat and the XII European Symposium on the Quality of Eggs and Egg 531 Products, Prague.

532 SHAND, P.J., SOFOS, J.N. \& SCHMIDT, G.R. (1994) Kappa-carrageenan, sodium chloride 533 and temperature affect yield and texture of structured beef rolls. Journal of Food Science, 49: $534 \quad 447-457$.

535 SHEN, Q.W., MEANS, W.J., UNDERWOOD, K.R., THOMPSON, S.A., ZHU, M.J., 536 MCCORMICK, R.J., FORD, S.P., ELLIS, M. \& DU, M. (2006) Early post-mortem AMP537 activated protein kinase (AMPK) activation leads to phosphofructokinase-2 and -1 (PFK-2 538 and PFK-1) phosphorylation and the development of pale, soft, and exudative (PSE) 539 conditions in porcine longissimus muscle. Journal of Agriculture and Food Chemistry, 54: $540 \quad 5583-5589$.

541 SMITH, L. \& CONRAD, H. (19560 A study of the kinetics of the oxidation of cytochrome c 542 by cytochrome c oxidase. Archives of Biochemistry and Biophysics, 63: 403-413.

543 TOWBIN, H., STAEHELIN, T. \& GORDON, J. (1979) Electrophoresis transfer of proteins 544 from polyacrylamide gels to nitrocellulose sheets: Procedure and some applications. 545 Proceedings of the National Academy of Science (USA), 76: 4350-4354.

546 WARNER, R.D., KAUFFMAN, R.G. \& GREASER, M.L. (1997) Muscle protein changes 547 post-mortem in relation to pork quality traits. Meat Science, 45: 339-352.

548 WARRIS, P.D. \& BROWN, S.N. (1987) The relationships between initial pH, reflectance and 549 exudation in pig muscle. Meat Science, 20: 65-74.

550 WARRIS, P.D., KESTIN, S.C., BROWN, S.N. \& BECIS, E.A. (1988) Depletion of glycogen 551 reserves in fasting broiler chickens. British Poultry Science, 29: 149-154. 
552 WEGENER G. \& KRAUSE U. (2002) Different modes of activating phosphofructokinase, a 553 key regulatory enzyme of glycolysis, in working vertebrate muscle. Biochemical Society 554 Transactions, 30: 264-270.

555 WILSON, G.G.I. \& VAN LAACK, R.L.J.M. (1999) Sarcoplasmic proteins influence water556 holding capacity of pork myofibrils. Journal of the Science of Food and Agriculture, 79: 557 1939-1942.

558 WYNVEEN, E.J., BOWKER, B.C., GRANT, A.L., DEMOS, B.P. \& GERRARD, D.E. 559 (1999) Effects of muscle pH and chilling on development of PSE-like turkey breast meat. 560 British Poultry Science, 40: 253-256. 
GR GN

562

563

564

565

LIS

566

567

568

569

570

571

572

573

574

575

HIS

576

577

578

579

580

581

582

583

584

585

Pellet

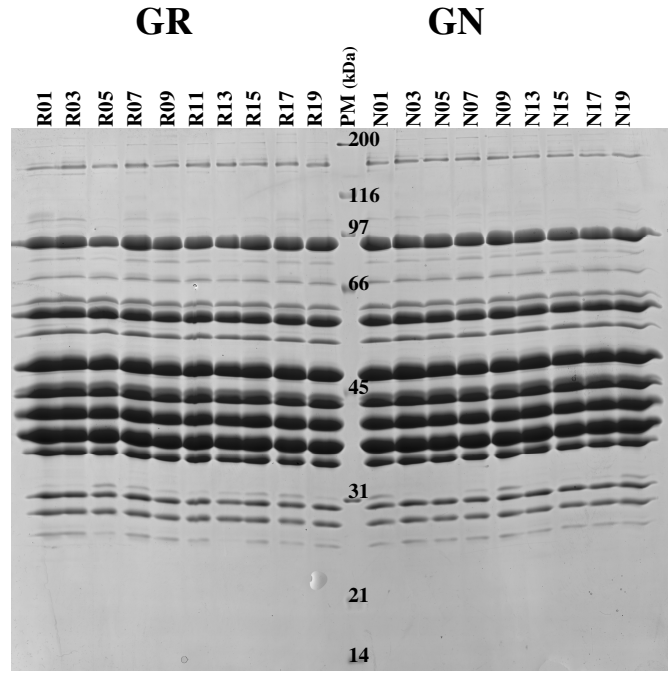

GR GN

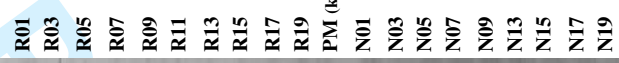

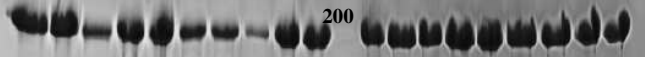

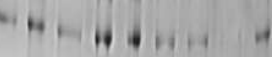

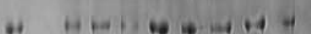

$\leftarrow 200 \mathrm{kDa}$

116

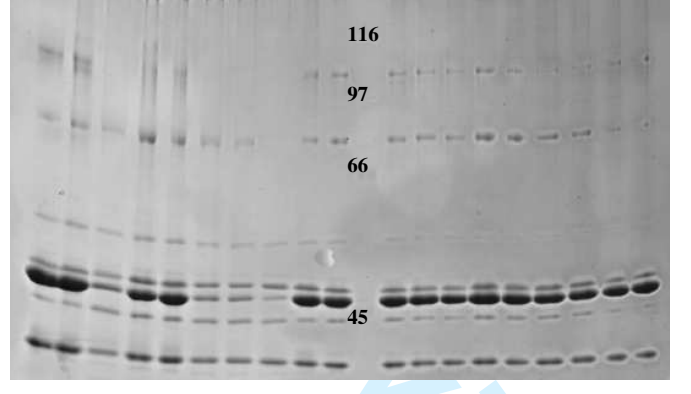

$\leftarrow \quad 45 \mathrm{kDa}$

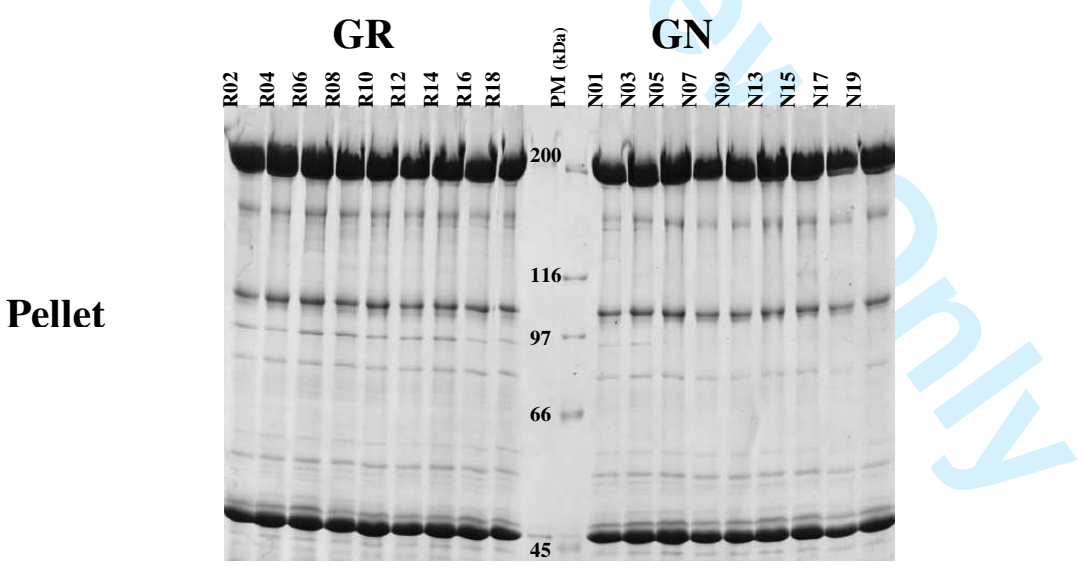

588

589

590

Figure 1. Examples of SDS-Page gels from muscular proteins extracted with different buffers

591 (LIS=Low Ionic Strength, HIS=High Ionic Strength, Pellet= residue after Lis and His buffers

592 extractions) at 24 h post mortem from GR (Fast Glycolysing) and GN (Normal Glycolysing)

593 turkeys. One different animal is present per lane and arrows indicate major variation in band

594 staining. 


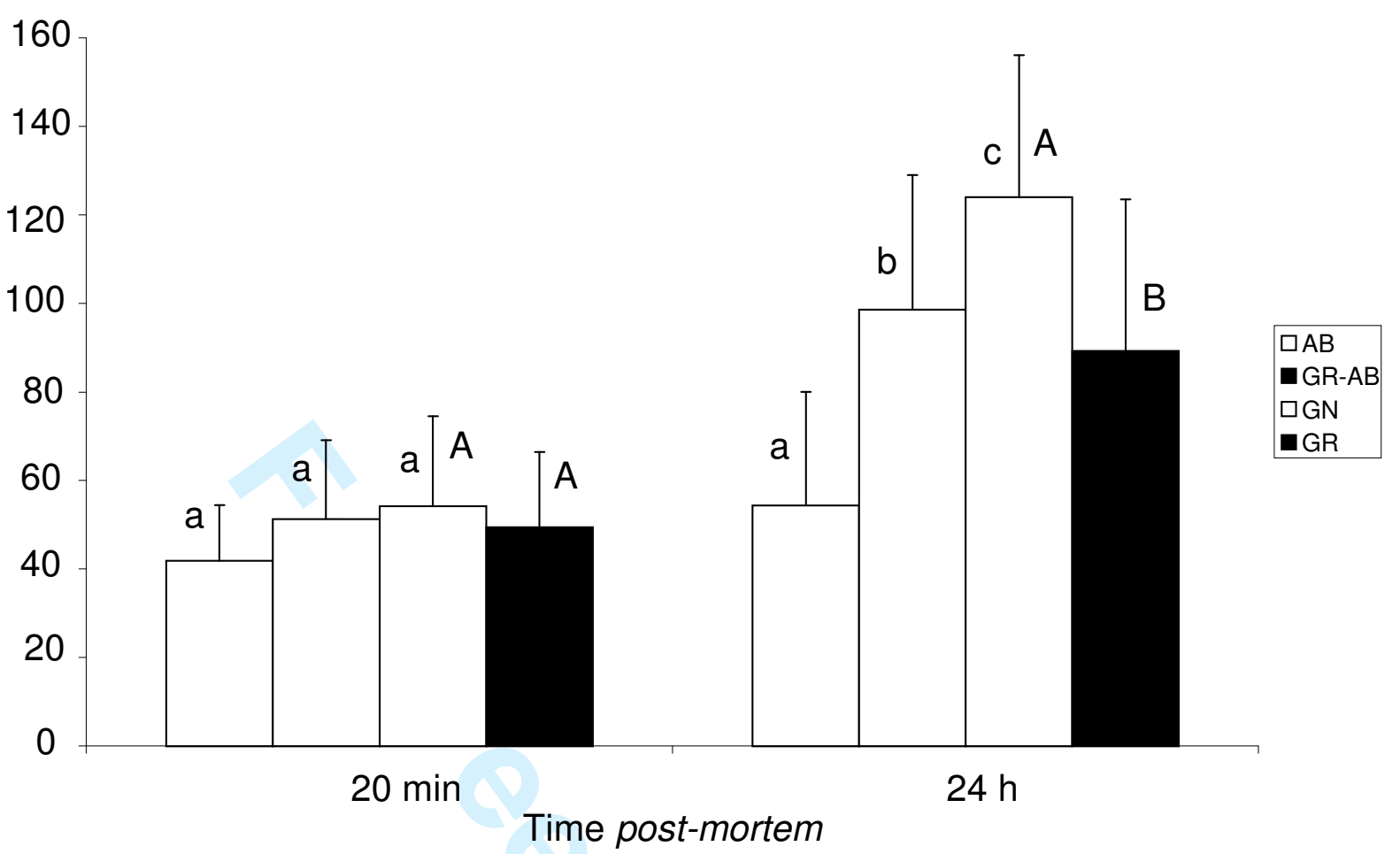

595

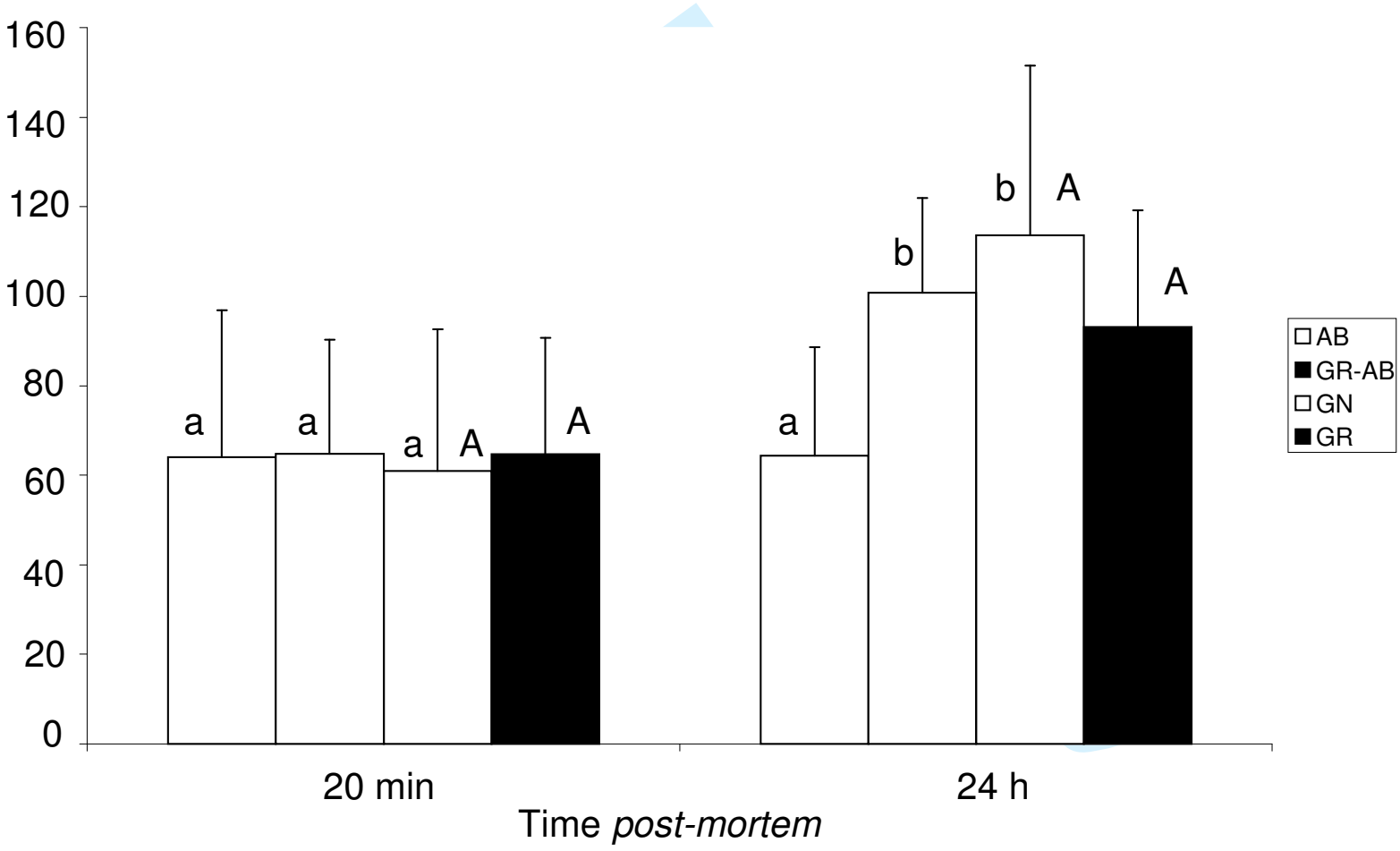

598 Figure 2. Western blot values with antibody against Myosin Heavy Chain (top) and actin 599 (bottom) at $20 \mathrm{~min}$ and $24 \mathrm{~h}$ post mortem for the different groups of turkeys. Values are means $600 \pm S D$ and are expressed as percentages of reference protein. $G N=$ Normal Glycolysing, GR $601=$ Fast Glycolysing, $A B=$ Abnormal $G R, G R-A B=G R$ animals not $A B{ }^{a, b} A B, G R-A B$ and $602 G N$ means with different superscripts differ significantly at $P<0.05,{ }^{A, B} G N$ and $G R$ means 603 with different superscripts differ significantly at $P<0.05$. 
604

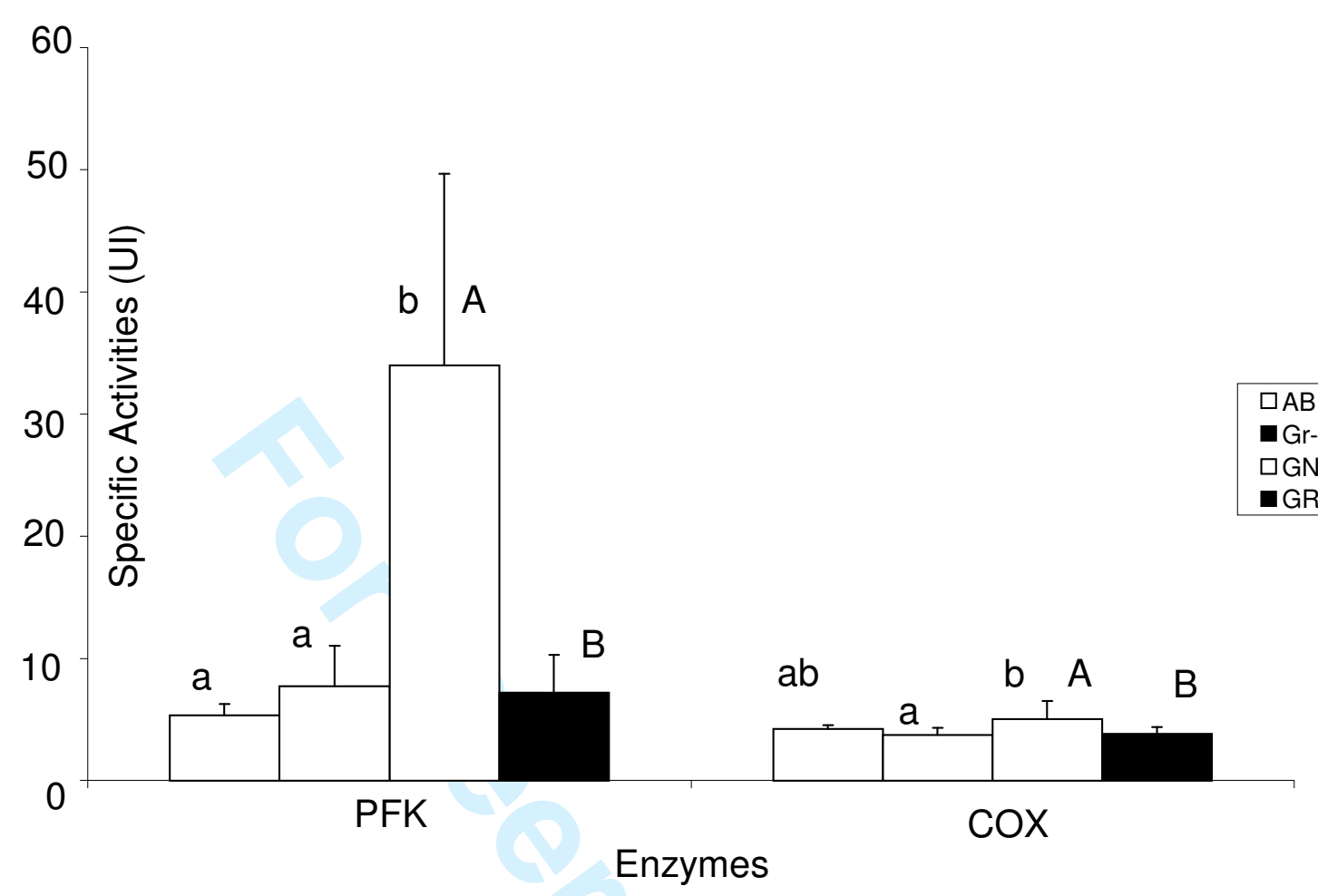

Figure 3. Specific activities (in UI) of the PFK (PhosphoFructoKinase) and cytochrome 607 oxydase c (COX) enzymes in the different groups of turkeys. Values are means $\pm S D$. GN = 608 Normal Glycolysing, GR = Fast Glycolysing, $A B=$ Abnormal GR, GR-AB = GR birds not $609 A B .{ }^{a, b} A B, G R-A B$ and $G N$ means with different superscripts differ significantly at $P<0.05$, $610{ }^{A, B} G N$ and $G R$ means with a different superscript differ significantly at $P<0.05$. 
611 Table 1. Percentage of proteins extracted by buffer with increasing ionic strength at 20 min 612 or 24 h post-mortem in different groups of turkeys. Values are means $\pm S D$ and expressed as 613 percentages of total proteins

\begin{tabular}{|l|l|r|c|c|c}
\hline $\begin{array}{c}\text { Time } \\
\text { post mortem }\end{array}$ & \multicolumn{1}{|c|}{$\%$} & \multicolumn{1}{c|}{$\mathrm{AB}$} & GR-AB & GN & \multicolumn{1}{c}{ GR } \\
\hline $20 \mathrm{~min}$ & LIS & $22.7 \pm 2.38^{\mathrm{a}}$ & $25.0 \pm 0.92^{\mathrm{ab}}$ & $25.0 \pm 1.03^{\mathrm{b}}$ & $24.8 \pm 0.93$ \\
& HIS & $5.9 \pm 1.03^{\mathrm{a}}$ & $7.0 \pm 0.78^{\mathrm{b}}$ & $7.6 \pm 1.17^{\mathrm{b}, \mathrm{A}}$ & $6.8 \pm 1.00^{\mathrm{B}}$ \\
& Pellet & $23.2 \pm 5.10^{\mathrm{a}}$ & $26.3 \pm 3.33^{\mathrm{a}}$ & $30.7 \pm 2.87^{\mathrm{b}, \mathrm{A}}$ & $26.3 \pm 3.09^{\mathrm{B}}$ \\
\hline $24 \mathrm{~h}$ & LIS & $23.6 \pm 0.69^{\mathrm{a}}$ & $27.0 \pm 1.67^{\mathrm{b}}$ & $29.3 \pm 1.13^{\mathrm{c}, \mathrm{A}}$ & $26.3 \pm 2.05^{\mathrm{B}}$ \\
& HIS & $5.4 \pm 0.95^{\mathrm{a}}$ & $16.6 \pm 4.45^{\mathrm{b}}$ & $18.2 \pm 4.67^{\mathrm{b}, \mathrm{A}}$ & $14.4 \pm 6.00^{\mathrm{B}}$ \\
& Pellet & $32.5 \pm 5.46^{\mathrm{a}}$ & $27.8 \pm 6.01^{\mathrm{ab}}$ & $27.0 \pm 4.36^{\mathrm{b}}$ & $28.8 \pm 6.07$ \\
\hline
\end{tabular}

$614{ }_{\mathrm{a}, \mathrm{b}} \mathrm{AB}, \mathrm{GR}-\mathrm{AB}$ and GN means with different superscripts differ significantly at $P<0.05$.

$615{ }^{\mathrm{A}, \mathrm{B}} \mathrm{GN}$ and GR means with different superscripts differ significantly at $P<0.05$.

$616 \mathrm{GN}=$ Normal Glycolysing, $\mathrm{GR}=$ Fast Glycolysing, $\mathrm{AB}=$ Abnormal GR, GR-AB $=\mathrm{GR}$ 617 turkeys not AB. LIS = Low Ionic Strength buffer, His = High Ionic Strength buffer, Pellet $=$ 618 residue after Lis and His buffers extractions. 
Table 2. Meat quality parameters in different groups of turkeys. Values are means \pm SD

\begin{tabular}{lllll}
\hline & \multicolumn{1}{c}{$\mathrm{AB}$} & \multicolumn{1}{c}{ GR-AB } & \multicolumn{1}{c}{ GN } & \multicolumn{1}{c}{ GR } \\
\hline $\mathrm{pH}_{20}$ & $5.8 \pm 0.12^{\mathrm{a}}$ & $5.8 \pm 0.39^{\mathrm{a}}$ & $6.2 \pm 0.01^{\mathrm{b}, \mathrm{A}}$ & $5.8 \pm 0.07^{\mathrm{B}}$ \\
$\mathrm{pH}_{\mathrm{u}}$ & $5.8 \pm 0.03$ & $5.8 \pm 0.09$ & $5.8 \pm 0.09$ & $5.8 \pm 0.08$ \\
$\mathrm{~T}_{20}\left({ }^{\circ} \mathrm{C}\right)$ & $43.1 \pm 2.22^{\mathrm{a}}$ & $41.7 \pm 0.91^{\mathrm{ab}}$ & $41.7 \pm 0.66^{\mathrm{b}}$ & $42.1 \pm 1.37$ \\
Drip losses (\%) & $6.2 \pm 1.47^{\mathrm{a}}$ & $3.7 \pm 1.06^{\mathrm{b}}$ & $3.2 \pm 0.08^{\mathrm{b}, \mathrm{A}}$ & $4.2 \pm 1.45^{\mathrm{B}}$ \\
Thawing losses (\%) & $4.8 \pm 0.33$ & $4.5 \pm 2.35$ & $4.0 \pm 1.79$ & $4.5 \pm 2.07$ \\
Cooking losses (\%) & $17.7 \pm 1.24^{\mathrm{a}}$ & $14.4 \pm 2.05^{\mathrm{b}}$ & $14.2 \pm 2.17^{\mathrm{b}}$ & $15.1 \pm 2.34$ \\
$\mathrm{~F}_{\max }(\mathrm{N})$ & $43.5 \pm 14.83^{\mathrm{a}}$ & $30.8 \pm 11.04^{\mathrm{a}}$ & $25.0 \pm 4.25^{\mathrm{b}, \mathrm{A}}$ & $33.4 \pm 12.57^{\mathrm{B}}$ \\
$\mathrm{L}^{*}$ & $53.0 \pm 2.87^{\mathrm{a}}$ & $49.4 \pm 1.89^{\mathrm{b}}$ & $49.1 \pm 2.92^{\mathrm{b}}$ & $50.1 \pm 2.51$ \\
$\mathrm{a}^{*}$ & $7.3 \pm 1.04^{\mathrm{a}}$ & $5.5 \pm 1.147^{\mathrm{b}}$ & $5.1 \pm 0.60^{\mathrm{b}, \mathrm{A}}$ & $5.9 \pm 1.34^{\mathrm{B}}$ \\
$\mathrm{b}^{*}$ & $0.76 \pm 1.31$ & $0.14 \pm 0.85$ & $0.19 \pm 0.64$ & $0.26 \pm 0.92$ \\
Processing yield (\%) & $82.1 \pm 1.34^{\mathrm{a}}$ & $89.0 \pm 4.17^{\mathrm{b}}$ & $90.4 \pm .14^{\mathrm{b}, \mathrm{A}}$ & $87.6 \pm 4.68^{\mathrm{B}}$ \\
\hline
\end{tabular}

${ }^{\mathrm{a}, \mathrm{b}} \mathrm{AB}, \mathrm{GR}-\mathrm{AB}$ and $\mathrm{GN}$ means with different superscripts significantly differ at $P<0.05$. ${ }^{\mathrm{A}, \mathrm{B}} \mathrm{GN}$ and GR means with different superscripts significantly differ at $P<0.05$.

$\mathrm{GN}=$ Normal Glycolysing, $\mathrm{GR}=$ Fast Glycolysing, $\mathrm{AB}=$ Abnormal GR, GR-AB $=\mathrm{GR}$ turkeys not $\mathrm{AB}$. 
627 Table 3. Main energetic metabolites contain in Pm muscle of turkeys from the different groups at 20 min and 24 h post-mortem. Values are means $\pm S D$ and are expressed in $\mu m o l e s / g$ tissue except for the glycolytic potential (GP) values which are expressed in $\mu$ moles

\begin{tabular}{clllll}
\hline $\begin{array}{c}\text { Time } \\
\text { post mortem }\end{array}$ & & \multicolumn{4}{c}{ AB lactate/g tissue } \\
\hline 20 min & Glycogen & $1.8 \pm 1.42^{\mathrm{a}}$ & \multicolumn{1}{c}{ GR-AB } & \multicolumn{1}{c}{ GN } & \multicolumn{1}{c}{ GR } \\
& G6P & $0.34 \pm 0.29$ & $0.20 \pm 0.20$ & $0.21 \pm 0.22$ & $0.23 \pm 0.22$ \\
& Glucose & $2.6 \pm 0.57^{\mathrm{a}}$ & $2.5 \pm 0.55^{\mathrm{a}}$ & $1.6 \pm 0.37^{\mathrm{b}, \mathrm{A}}$ & $2.5 \pm 0.54^{\mathrm{B}}$ \\
& Lactate & $102.8 \pm 11.19^{\mathrm{a}}$ & $98.8 \pm 6.80^{\mathrm{a}}$ & $78.1 \pm 6.03^{\mathrm{b}, \mathrm{A}}$ & $99.6 \pm 7.68^{\mathrm{B}}$ \\
$24 \mathrm{~h}$ & Glycogen & $0.27 \pm 0.15$ & $0.71 \pm 0.52$ & $0.79 \pm 0.66$ & $0.62 \pm 0.50$ \\
& G6P & $0.82 \pm 0.52$ & $2.03 \pm 2.08$ & $2.29 \pm 1.43$ & $1.77 \pm 1.91$ \\
& Glucose & $2.7 \pm 0.99$ & $2.4 \pm 0.82$ & $2.2 \pm 0.82$ & $2.5 \pm 0.84$ \\
& Lactate & $115.2 \pm 9.03$ & $115.7 \pm 6.44$ & $114.9 \pm 10.13$ & $115.6 \pm 6.78$ \\
& GP & $122.7 \pm 11.66$ & $126.0 \pm 9.88$ & $125.3 \pm 13.54$ & $125.3 \pm 9.96$
\end{tabular}

631

632

633

634

635

636

637

638

${ }^{\mathrm{a}, \mathrm{b}}$ Means with different superscript significantly differ $(P<0.05)$ between $\mathrm{AB}, \mathrm{GR}-\mathrm{AB}$ and GN.

${ }^{\mathrm{A}, \mathrm{B}}$ Means with different superscript significantly differ $(P<0.05)$ between $\mathrm{GN}$ and GR.

$\mathrm{GN}=$ Normal Glycolysing, $\mathrm{GR}=$ Fast Glycolysing, $\mathrm{AB}=$ Abnormal GR, GR-AB = GR turkeys not $\mathrm{AB}$. 